\title{
'Magic mothers and wicked criminals': Exploring narrative and role in a drama programme with women prisoners
}

\begin{abstract}
This article explores narrative and role as key elements of an applied theatre project with women in an Australian prison. The research story has arisen out of the first stages of data analysis from the project, where a range of sometimes conflicting narratives and roles emerged as prevalent within the workshop process itself, as well as its surrounds; and where narrative and role helped to articulate the complexity of the applied theatre practice/research experience. The practice and research methodologies for the project were inextricably entwined, furthering James Thompson's (2003) notion of 'theatre action research' and Hughes et al.'s (2011) 'practised method'. These practitioner/researchers recognize applied theatre as both the process and the object of inquiry, a dynamic relationship that complicates both the research narrative and the roles played within it.
\end{abstract}

\section{KEYWORDS}

prison theatre women prisoners practised method drama workshops living stories playbuilding 


\section{BACKGROUND}

As part of a larger doctoral study, I led a 24-session drama workshop programme with women at Brisbane Women's Correctional Centre (BWCC) over four months. The 'Living Stories' programme focused on drama games, improvisation and devised work, culminating in a final presentation to peers and staff. I aimed to explore how drama might be a positive activity for women prisoners - particularly in Australia, where its use appears to be relatively rare and undocumented. From within this practical frame, I also hoped we might collaborate to uncover a research story that would foreground the voices of the women participants. Yet genuine and ongoing collaboration with participants in a prison context can be difficult, challenging such notions as empowerment and voice (see Ghaye et al. 2008). The data from the project consisted of group and one-to-one interviews with the women, voice recorded sections of workshop sessions and the final performance, and my own reflective journal and field observations, as well as documentation such as workshop plans, scripts and e-mails. Collaboration with the participants was limited to the workshop programme itself, and a small amount of interpretation and analysis that took place in situ and shortly afterwards. I have attempted to maintain consultation with most of the participants through mail and e-mail contact; however, this has been limited by restricted access and the pressing deadlines of the doctoral project.

My interest in theatre forms that draw upon participants' lived experiences, such as verbatim, documentary, autobiographical performance and reminiscence theatre, underpinned my methodology as both practitioner and researcher, influencing how I approached the workshops and the data, and how I am beginning to articulate the research story. Through early analysis of the data, a story has emerged about the boundary between fact and fiction within the narratives and roles that were represented in and around the workshop space. By experimenting with verbatim-based scripted prose, I hope to express this complexity and the immediacy of action within the project, and to bring the cast of characters and their voices to the fore. This has involved re-sequencing and re-locating some conversations, as well as merging some once separate comments into monologues. However, none of this editing has removed any ideas from their original context. I must be clear that $I$ have edited this work, and used a certain amount of creative licence in ways that I hope will engage the reader more effectively with the discoveries that $I$ am beginning to make about the project. Through this process, the voices of the women are broadcast through the condensers, mixers and amplifiers of my interpretation as both artist and researcher, rather than the more agentic notion of voice that is aspired to, if not always achieved, in participatory research. Alongside the participants, there is my voice as practitioner/researcher, through the reflections and observations made during the workshop programme and my subsequent search for meaning.

In terms of narrative research, some scholars believe that isolating and rearranging verbatim testimony can compromise the integrity of the research narrative (see Saldaña 2009). In terms of creating a dramatic narrative based on lived experience, this is precisely what often occurs in the process of interpreting and structuring the work (see Govan et al. 2007; Hammond and Steward 2008; Prendergast and Saxton 2009; Schweitzer 2007). Both enterprises strive to foreground the voices of participants and make claims for a 
certain level of authenticity or veracity, with all the ontological questions that this raises. However, in both there is an acknowledgement that fact and fiction are 'muddied' (Clandinin and Connelly 2000: 179; see also Clough 2002: 11-19) or that they are 'interrelated and mutually embedded' (Nicholson 2005: 66; see also Reinelt 2009). Throughout the range of disciplines that apply theatre for social purposes, it is precisely its situation between fiction and reality that creates possible shifts within participants that can be called (depending on the form) therapeutic, educative or political (see Boal 2000; Courtney 1989, 1995; Moreno 1975; O'Toole 1992; Wagner 1976; Winnicott 1991).

This blurring between fact and fiction echoes the often-blurred position of 'Living Stories' within both practice and research. The practice and research methodologies for the project were inextricably entwined, furthering James Thompson's (2003) notion of 'theatre action research' and Hughes et al.'s (2011) 'practised method'. These practitioner/researchers recognize applied theatre as both the process and the object of inquiry, a dynamic relationship that complicates the research narrative itself, as well as the roles played within it. Hughes and colleagues propose practised method as a term 'that might usefully complement the "practice as research" and "research into practice" categorisations' within applied theatre (2011: 188). In 'Living Stories', action research, practice as research and research into practice all occurred at different times. For me, the term 'practised method' accommodates all possibilities, and allows for movement to occur between them. This article represents an attempt to come to grips with this notion of practised method in applied theatre, and specifically as it was experienced in 'Living Stories'. Also pressing for me at this stage in the research is how best to 'analyse' the 'data' (for want of more artful terms) within practised method, and how to begin transforming this exploration into credible and trustworthy research stories.

While this study is not positioned within narrative inquiry, I see narrative as key to exploring within practised method, and articulating its complexity. From an epistemological perspective, Jerome Bruner's (1986) view of narrative as a way of understanding human existence has influenced a 'narrative turn' in qualitative inquiry (Chase 2005). Bruner and subsequent interdisciplinary scholars and practitioners such as Clandinin and Connelly (2000), Cattanach (1996), Chase (2005), Dennis (2004), Nicholson (2003, 2005), Polkinghorne (1995) and Richardson and St Pierre (2005) all highlight narrative as central to understanding identity and experience, with many holding a commitment to bringing forth those narratives that may come from outside of the dominant discourses within society. Within reflective practice, narrative plays an integral part in navigating the journey of the practitioner (see Bolton 2005; Schön 1983). In 'Living Stories', I also follow Nicholson (2005) in seeing narrative as a dramaturgical element that manifests through the project within and across three frames: the performative frame of the dramatic scenes that we created as a group; the frame of our lived experiences - both inside and outside the workshop space; and the subsequent articulation of a research story. By extension, there existed a range of roles that we each played within these narratives, which I will discuss in more detail later. Narrative and role offer a way of exploring and describing the fluidity between these frames, and the blurriness between fact and fiction. They therefore offer a way of articulating what Dewey (1934) saw as the unity within aesthetic experience, which for me honours the artistry that is central to applied theatre. 


\section{THE STORY}

\section{Part 1: Groundhog Day}

The women prisoners and Sarah are seated on chairs in a circle.

Diane: It's numbing in here.

Emma: You don't think a lot.

Grace: You have your personal problems ...

Aamira: Pressurized.

Diane: It's like groundhog day and so we just do ... like even when you brush your teeth it's the same ...

Mandy: The only thing you don't get told what to do here is when you can go to the toilet. Everything's structured, so you don't have to think, you're just a robot - bzzzz (impersonates robot).

In pairs, the women have exchanged their life stories in four minutes. They must now re-enact their partner's life story using only mime. Half of the women stand in a line, each facing her partner, who is sitting down. They begin the re-enactment. They are lively and amused. They use inventive physical images for things such as childbirth, motherhood and arrest. The life stories all end in the same way: each woman stands facing her partner, her hands gripping imaginary prison bars as she gazes out into the middle distance. Later, the women reflect on the exercise.

Patti: They all began the same and they all ended the same.

Diane: They all ended in jail.

Sarah: Is that the end of the life story then?

Diane: No.

Patti: No, that's just where it's up to now, because when I get out I'm going to have more chapters in my life.

Mandy: It's a hiccup.

Diane: A momentary lapse of reality.

Sarah: For me there was a sense that life doesn't really happen in here, because that's where the story ended.

Diane: It's on hold.

Rachel: Yeah, it's all on hold.

Patti: This is just holding your breath.

Emma: You're waiting - playing a waiting game.

The 'Four-minute Life Story' exercise described here represents a moment of practice that explicitly invited participants to share their personal narratives. I introduced this exercise early in the program, hoping to gauge the participants' 
responses to sharing their own stories in a relatively fun, non-threatening way. Through the exercise, I also aimed to bring a small moment of validation to the teller of the story, as they watched it being re-enacted by their partner. In running the exercise and pursuing these aims, I was very much in role as reflective practitioner rather than researcher. Following on from the exercise, we began reflecting on it as a group - a process that has always been part of my practice. Yet my role as researcher and practitioner during such reflections started to blur, knowing as I did that the voice recorder that was running in the centre of the circle would now be picking up 'data' for my study.

At times the women were conscious of this as well - giving responses that were visibly directed towards the recorder. After seeing nearly every story end in prison, my question 'Is that the end of the life story?' came from the practitioner/researcher combined: from both positions, I wished to explore the notion that the life story ends in prison. Much later, after my first stage of analysing the data, a narrative theme of 'groundhog day' emerged. By arranging the verbatim testimony as I have done above, I attempt (using my sensibilities as both dramaturge and researcher) to artfully describe the context of the prison, support this notion of 'life on hold' and set the scene for the narratives which follow.

\section{Part 2: Another horizon}

Sarah conducts a group interview.

Sarah: What do you think of the drama programme so far?

Gwen: It gives us another horizon, it gives us another place to go - and by that I mean to try out our skills, to gain some confidence, you know, to stop thinking of ourselves as big horrible criminal type people and just being people. And that's huge. That's a big one.

The women reflect at the end of a session.

Gwen: You walk in the door for drama and if you have a problem or something, it stays out there. It's brilliant.

Tracy: It puts your head in a different place for the whole time.

Lola: There were a few minutes there when I forgot I was in here.

Aamira: You don't think you're in the prison. You just feel that you're outside.

...

Helen (Education Officer) is in her office being interviewed by Sarah.

Helen: It is like offering them freedom, it's like offering them a door that perhaps they wouldn't normally have.

The women all line up outside the closed door that leads into the education block and is guarded by an officer. The officer speaks on a radio to another staff member. 
Officer: I have them all here, can I let them in the door? Over.

Voice: No, there is a security malfunction. None of the doors will open.

Over.

Officer: What happened? Over.

Voice: The storm last night shorted them out. Over.

Officer: What do I do with them? Over.

Voice: Make them wait. Over.

Officer: What do I tell the drama teacher? Over.

Voice: She'll have to wait. Over and out.

It is day two of the program. The group is playing the improvisation game 'Knock at the Door'. Grace is inside her 'house', and Lola's task is to knock at the door and then find a way to get Grace to let her in. The women have been told that they must come up with a character and talk their way into the house, rather than use force. A few pairs have done the exercise successfully.

Lola approaches the door and knocks.

Lola: Knock, knock!

Grace: (Opening the door) Yes, can I help you?

Lola: (Pushing past Grace and walking into the house) Let me in!

Sarah: Lola, remember I said you can't use force - you need to talk your way in.

Lola: But I got in!

Sarah: Give it a try - come up with a character and talk your way in.

Lola: Fine.

Lola approaches the door and knocks.

Grace: (Opening the door) Hello?

Lola: (Mimes holding a gun in Grace's face) Let me in or I'll shoot.

Sarah: (Laughing) Lola, you're still using force - you need to find a reason to go inside: talk your way in.

Lola: But I'm no good at talking!

The rest of the group laughs at this. Someone says, 'Yes you are - that's what you do best!' Lola becomes visibly frustrated.

Lola: Okay, fine, let's do this. I know what to do. (Lola approaches the door holding her 'gun'. She kicks the door down and walks into the house shouting 'LET ME IN YOU FUCKING CUNT!'

'Another Horizon' was a theme that also emerged for me in the early stages of analysis. Gwen's use of this highly descriptive term became meaningful to 
me as a liminal setting for the narratives that took place within the project - a transitional place that could hold a range of paradoxes. Participants such as Mandy and Tina commented on the fact that they felt 'comfortable' and 'safe' to share and explore in this space. Yet still audible through the workshop room door was the constant white noise of the institution: routines and restrictions, power relations, work obligations, medical checks, fingerprint scanners, twoway radios and the roar of industrial toilets. In addition, moments such as Lola kicking down our imaginary door shattered the sense of ease and playfulness within. At times, this 'other horizon' felt unpleasant and unsafe.

Practitioners discuss the contradiction that exists between the potentially dehumanizing, mistrustful and paranoid world of the prison, and the trusting and supportive world that is aspired to, if not always created, within the context of the drama workshop space (see Balfour 2004; Clare 1998; Stamp 1998; White 1998). For me, our 'other horizon' was a place where a range of possibilities coexisted: the possibility for escape, creative freedom and exploration; and the possibility for danger, paranoia and the stagnation of 'Groundhog Day'. In shaping the dramatic narrative above, I have used the motif of the door, as well as juxtaposition, to demonstrate the dichotomy between safety and danger in the workshop room, in order to create dramatic tension and elicit an aesthetic response in the reader. In addition, our other horizon contained within it the possibility for a range of other, sometimes oppositional, ideas to coexist: fact and fiction, role and self, research and practice - some of which are explored further below.

\section{Part 3: Being yourself and being somebody else}

The first two days of the drama program.

Sarah: Why are you interested in doing drama?

Karen: Because you can be somebody else. You can have an alter-ego.

Halfway through the drama program.

The reflections, discussions and themes explored up to this point have led Sarah to suggest using 'inspiring women from history' as a stimulus for playbuilding. Each woman chooses a figure from history and scenes are created from that character's life. The women discuss why they chose their character, and how the character connects to their own personality.

Gwen: I chose Caroline Chisholm because she was much more than just a face on a five dollar note. She did so much good work in a place that was unknown. She was a great lady - not famous or wealthy, just great. I'd like to be like her. I mean everybody would like to do that good I think, you know, even us wicked criminals would like to be as good as she was.

Sarah interviews Gwen about the drama program.

Gwen: I think people come out more in the drama. They, how can I say, they expose themselves more when they're relaxed - when they know they're not being watched by an officer or nobody's listening, they're 
not under any scrutiny, people relax and the real person comes across instead of the bound-up prison person - you get a real person comes out, and that's good.

Sarah: What is the 'bound-up prison person?'

Gwen: That is the person who is careful what they say, they're careful how they behave.

Emma: Brick-walling and guarded.

Gwen: Closing yourself down.

Helen: Institutionalized.

Sarah interviews Mandy. They are discussing her idea that the drama programme has allowed her to explore more emotions than just the two that exist in prison: happy or sad.

Sarah: So you've said you can be more honest in here with showing your feelings?

Mandy: Yeah. It took a while but, yeah, you realize you can let out all different emotions.

Sarah: As characters or as yourselves or both?

Mandy: Both. Because when you become a character there's different emotions there that you've got to ... you know what I mean? And you stop your emotions like Mandy, and be Mary's emotions.

Sarah: Why is showing different emotions important?

Mandy: It reminds me I am human. I'm not prison property like they carry on.

It is session 13. The group is small - only Grace, Rachel, Aamira and Gwen are present. They are doing an exercise in which they must create a superhero version of themselves, with special powers based on qualities they either have or wish they had. The women first draw the superhero and then, in pairs, create a statue of their superhero using their partner. They then introduce the superhero.

Gwen: This is Magic Mother. All right, it's a bit of a cop-out. Her special talent and ability is that she keeps her house spotless by a touch or a point. Everything is clean and sparkly. She also instils in her children a wonderful feeling of well-being. She offers care and compassion 24/7.

At the end of the session, Sarah is discussing the exercise with the group.

Sarah: What did people think of that last exercise?

Gwen: I think it was very hard. I couldn't think of any qualities. So the thing that I'm most used to is homemaking, so that's what I went for, 
because for 60 years I think that's what I've been doing. But for me it was quite difficult.

Sarah: Are you happy with that choice?

Gwen: Yeah. It's something I know I'm comfortable with. Old habits are hard to break. I'm learning new ones in here thank heavens.

Twelve days later, Sarah is interviewing Gwen one to one.

Sarah: So I'm interested in what you thought of exercises that asked you to draw upon your own personality and life experiences - for example, the superhero exercise?

Gwen: I was shocking at that. That was terrible (laughs).

Sarah: Why was that terrible? What was terrible about it?

Gwen: Because of all the things I've done, and I've done things that most other women would never imagine doing - I've climbed waterfalls and I've been underground diving in caves - I've done things women don't do. I don't know what the record books say, but I know factually that I was one of the first female house painters in the state of Queensland. And it sounds small, but it's quite a thing. There are so many things I've done in my life and places I've been, and when you asked me, I went 'housewife'.

\section{They laugh together.}

The fields of sociology (Goffman 1969), performance theory (Heddon 2008; Schechner 2003), psychodrama (Blatner 2000; Moreno 1975), drama therapy (Duggan and Grainger 1997; Emunah 1994; Landy 1993, 1994, 2001) and, by extension, applied theatre theory (Nicholson 2003, 2005; Weaver 2009), have conceptualized self and role as interchangeable, potentially inhabiting both fact and fiction. As a practitioner, I purposely introduced exercises and processes that might invite the women to performatively explore this boundary between role and self. In reflective conversations, I was curious as both practitioner and researcher about their experience of exploring this boundary. Yet this was not a predetermined agenda within the project, but emerged and grew as I/we acted and reflected. Inspired by Saldaña's (2009) 'dramaturgical' coding method (2009: 102-05), I then undertook a phase of 'role coding' in which I explored the range of different roles, both factual and fictional, that were performed within 'Living Stories'. Gwen's experience of the 'magic mother' role demonstrates the changes that can occur in how the self is perceived and performed, both within and outside of the fictional frame. Her reflections on choosing Caroline Chisholm as a fictional character demonstrate a sense that she could use the role of this historical figure to transcend that of the 'wicked criminal'. Mandy identified that the drama programme allowed her to explore a range of emotions that moved her beyond the role of the 'bound-up prison person', and reconnect her with a sense of her humanity. The 'other horizon' therefore became a place where the intersections between these factual/fictional roles were explored, and where my role as practitioner/researcher itself constantly shifted in the execution of my practised method. 


\section{Part 4: Playing with fire}

During the workshop, Sarah is using the character of Joan of Arc for a play-building exercise. She passes around a collection of different pictures of St Joan.

Sarah: Pick one of those pictures that you particularly like, for whatever reason, just choose one. If somebody else chooses it, that's okay.

Tina: Can you pass us that one with the white dress? Thank you.

This is an image of Joan of Arc being burned at the stake. Sarah asks the group to describe the picture and explain why they chose it. It comes around to Tina.

Tina: I chose this picture because it shows her bravery and her faith in God that she believes in.

Sarah: How does it show her bravery?

Tina: Well she's got flames and fire all around her ...

Gwen: But she's not screaming.

Tina: Yeah.

Sarah: And what about her faith? What tells you that she's still got her faith?

Tina: Well as the flames are getting to her, and she's holding the cross and she looks like she's looking up to heaven.

It is twelve years ago. Tina is in her cell. She ceremonially piles everything into the middle of the small room: sheets, blankets, books, photographs. Her cellmate is watching, unmoving but also unsure. Tina has an enigmatic smile on her face as she creates her pyre. She glances conspiratorially across to her cellmate and holds up an orange Bic cigarette lighter. By now her cellmate has moved closer to the door. Tina flicks the wheel of the lighter and it sparks to life. She bends down and begins lighting the most combustible items - paper, dry cloth. The fire's ferocity surprises them both. Tina then sits down in the farthest corner of the cell from the door, waiting.

Tina related this final story to me in conversation a few days following the Joan of Arc workshop, although I had sensed that there was an issue during the workshop when she said she did not want to represent the burning at the stake. As she spoke to me, the imagery that came to mind was vivid and inherently dramatic. As a practitioner, it was a stark reminder of the risks involved in traversing the boundary between fact and fiction within role; it brought back the sense of danger in our 'other horizon'. As a researcher, it presented to me a compelling piece of 'data' in my construction of a research narrative. Aesthetically, and in terms of the research, I felt compelled to include my fictionalized description of Tina's story above and set it against the events of the Joan of Arc workshop. Here again, the boundary between fact and fiction has become blurred as I move from the role of practitioner to that of researcher in articulating the practice/research experience, while attempting to retain some sense of aesthetic unity. 


\section{THE STORY CONTINUES}

This research story represents the beginning of my exploration into this fluid border between fact and fiction as it manifested in the roles and narratives of 'Living Stories'. It also represents an attempt to understand and articulate the border between practice and research within the notion of practised method. In terms of the practice, the exercises that I have described here explicitly called upon participants to make connections between themselves and the roles they played. In terms of both practice and research, I remained interested in these connections, and at times highlighted them through questioning and reflecting during the workshop process. In terms of the research, I have begun to incorporate these ideas into my analysis and now, as I begin to articulate the research stories from our experience, I strive to achieve a balance between artistry and rigour, as I search for ways in which to represent these intersections through a dramatic/research narrative. Yet in all of this, I return to my struggle with the concept of voice. Where the research process continues to be imbued with creativity, the women with whom I co-created the 'Living Stories' programme are now distant and/ or absent. Consequently, their voices and characters may be dramatically present in the way that they might be in a piece of reminiscence or verbatim theatre, but they have grown increasingly silent as we have moved away from the midst of the project.

\section{REFERENCES}

Balfour, M. (2004), Theatre in Prison: Theory and Practice, Bristol: Intellect.

Blatner, A. (2000), Foundations of Psychodrama: History, Theory, and Practice, 4th edn, New York: Springer.

Boal, A. (2000), Theater of the Oppressed, London: Pluto Press.

Bolton, G. (2005), Reflective Practice: Writing and Professional Development, 2nd edn, London: Sage.

Bruner, J. S. (1986), Actual Minds, Possible Worlds, Cambridge, MA: Harvard University Press.

Cattanach, A. (1996), Drama for People with Special Needs, 2nd edn, London: A. \&. C. Black.

Chase, S. (2005), 'Narrative Enquiry: Multiple Lenses, Approaches, Voices', in N.K. Denzin and Y.S. Lincoln (eds), The Sage Handbook of Qualitative Research, 3rd edn, Thousand Oaks CA: Sage, pp. 651-79.

Clandinin, D. J. and Connelly, F.M. (2000), Narrative Inquiry: Experience and Story in Qualitative Research, San Francisco: Jossey-Bass.

Clare, R. (1998), 'Creating Drama through Advanced Improvisation in Prisons', in J. Thompson (ed.), Prison Theatre: Perspectives and Practices, London: Jessica Kingsley, pp. 145-69.

Clough, P. (2002), Narratives and Fictions in Educational Research, Buckingham: Open University Press.

Courtney, R. (1989), Play, Drama \& Thought: The Intellectual Background to Dramatic Education, 4th edn, Toronto: Simon \& Pierre.

— (1995), Drama and Feeling: An Aesthetic Theory, Montreal: McGill-Queen's University Press.

Dennis, R. (2004), 'Public Performance, Personal Story: A Study of Playback Theatre', unpublished PhD thesis, http://www4.gu.edu.au: 8080/adt-root/ public/adt-QGU20050211.115221/index.html. Accessed 9 June 2012.

Dewey, J. (1934), Art as Experience, New York: Capricorn. 
Duggan, M. and Grainger, R. (1997), Imagination, Identification and Catharsis in Theatre \& Therapy, Dordrecht: Springer.

Emunah, R. (1994), Acting for real: drama therapy process, technique, and performance, New York: Brunner/Mazel Publishers.

Ghaye, T., Melander-Wikman, A., Kisare, M., Chambers, P., Bergmark, U., Kostenius, C. et al. (2008), 'Participatory and Appreciative Action and Reflection (PAAR): Democratizing Reflective Practices', Reflective Practice: International and Multidisciplinary Perspectives, 9: 4, pp. 361-97.

Glynn, M. (1998), 'Silent Voices': Working with Black Male Inmates - a Perspective', in J. Thompson (ed.), Prison Theatre: Perspectives and Practices, London: Jessica Kingsley, pp. 171-82.

Goffman, E. (1969), The Presentation of Self in Everyday Life, London: Allen Lane.

Govan, E., Nicholson, H. and Normington, K. (2007), Making a Performance: Devising Histories and Contemporary Practices, London: Routledge.

Hammond, W. and Steward, D. (eds) (2008), Verbatim Verbatim: Contemporary Documentary Theatre, London: Oberon Books.

Heddon, D. (2008), Autobiography \& Performance, Basingstoke: Palgrave Macmillan.

Hughes, J., Kidd, J. and MacNamara, C. (2011), 'The Usefulness of Mess: Artistry, Improvisation and Decomposition in the Practice of Research in Applied Theatre', in B. Kershaw and H. Nicholson (eds), Research Methods in Theatre and Performance, Edinburgh: Edinburgh University Press, pp. 186-209.

Idoko, E. F. (2004), 'Theatre and Ecclecticism: The "Tandari" Experience', in M. Balfour (ed.), Theatre in Prison: Theory and Practice, Bristol: Intellect, pp. 179-87.

Landy, R. J. (1993), Persona and Performance: The Meaning of Role in Drama, Therapy, and Everyday Life, London: Jessica Kingsley.

- (1994), Drama Therapy: Concepts, Theories, and Practices, 2nd edn, Springfield, IL: C.C. Thomas.

— (2001), New Essays in Drama Therapy: Unfinished Business. Springfield, IL: Charles C. Thomas.

Moller, L. (2003), 'A Day in the Life of a Prison Theatre Program', The Drama Review, 47: 1, pp. 49-73.

Moreno, J. L. (1975), Psychodrama, New York: Beacon House.

Nicholson, H. (2003), 'The Performance of Memory: Drama, Reminiscence and Autobiography' NJ: Drama Australia Journal, 27: 2, pp. 79-92.

(2005), Applied Drama: The Gift of Theatre, Basingstoke: Palgrave Macmillan.

O'Toole, J. (1992), The Process of Drama: Negotiating Art and Meaning. London: Routledge.

Polkinghorne, D.E. (1995), 'Narrative Configuration in Qualitative Analysis', in J. A. Hatch and R. Wisniewski (eds), Life History and Narrative, London: Falmer Press, pp. 5-24.

Prendergast, M. and Saxton, J. (eds), (2009), Applied Theatre: International Case Studies and Challenges for Practice, Bristol: Intellect.

Reinelt, J. (2009), 'The Promise of Documentary', in A.F.C. Megson (ed.), Get Real: Documentary Theatre Past and Present, New York: Palgrave Macmillan, pp. 6-23. 
Richardson, L. and St Pierre, E.A. (2005), 'Writing: A Method of Enquiry', in N.K. Denzin and Y.S. Lincoln (eds), The Sage Handbook of Qualitative Research, 3rd edn, Thousand Oaks, CA: Sage, pp. 959-78.

Saldaña, J. (2009), The Coding Manual for Qualitative Researchers, London: Sage. Schechner, R. (2003), Performance Theory, 2nd edn, New York: Routledge.

Schön, D.A. (1983), The Reflective Practitioner: How Professionals Think in Action, New York: Basic Books.

Schweitzer, P. (2007), Reminiscence Theatre: Making Theatre from Memories, London: Jessica Kingsley.

Stamp, S. (1998), Holding On: Dramatherapy with Offenders, in J. Thompson (ed.), Prison Theatre: Perspectives and Practices, London: Jessica Kingsley, pp. 89-108.

Thompson, J. (2003), Applied Theatre: Bewilderment and Beyond, New York: Peter Lang.

Tocci, L. (2007), The Proscenium Cage: Critical Case Studies in US Prison Theatre Programs, Youngstown, NY: Cambria Press.

Wagner, B. J. (1976), Dorothy Heathcote: Drama as a Learning Medium, Washington, DC: National Education Association.

Weaver, L. (2009), 'Doing Time: A Personal and Practical Account of Making Performance Work in Prisons', in T. Prentki and S. Preston (eds), The Applied Theatre Reader, London: Routledge, pp. 55-61.

White, J. (1998), 'The Prisoner's Voice', in J. Thompson (ed.), Prison Theatre: Perspectives and Practices, London: Jessica Kingsley, pp. 183-96.

Winnicott, D.W. (1991), Playing and Reality, London: Routledge.

\section{SUGGESTED CITATION}

Woodland, S. (2013), "'Magic mothers and wicked criminals": Exploring narrative and role in a drama programme with women prisoners', Applied Theatre Research 1: 1, pp. 77-89, doi: 10.1386/atr.1.1.77_1

\section{CONTRIBUTOR DETAILS}

Sarah Woodland is a facilitator, director and educator in applied theatre, participatory arts and creative community engagement. For the past seventeen years, she has helped to develop and facilitate programmes in a broad range of contexts, using drama and other experiential group processes with a view to effecting positive transformation. Sarah has worked in Australia and the United Kingdom in the areas of prison theatre, reminiscence theatre, community cultural development, theatre in education, and training and professional development. She is currently completing a $\mathrm{PhD}$ in prison theatre, and teaches applied theatre at Griffith University in Brisbane. Sarah is also director of Theatre Scope - Griffith's arts-based community outreach arm.

E-mail: s.woodland@griffith.edu.au

Sarah Woodland has asserted her right under the Copyright, Designs and Patents Act, 1988, to be identified as the author of this work in the format that was submitted to Intellect Ltd. 


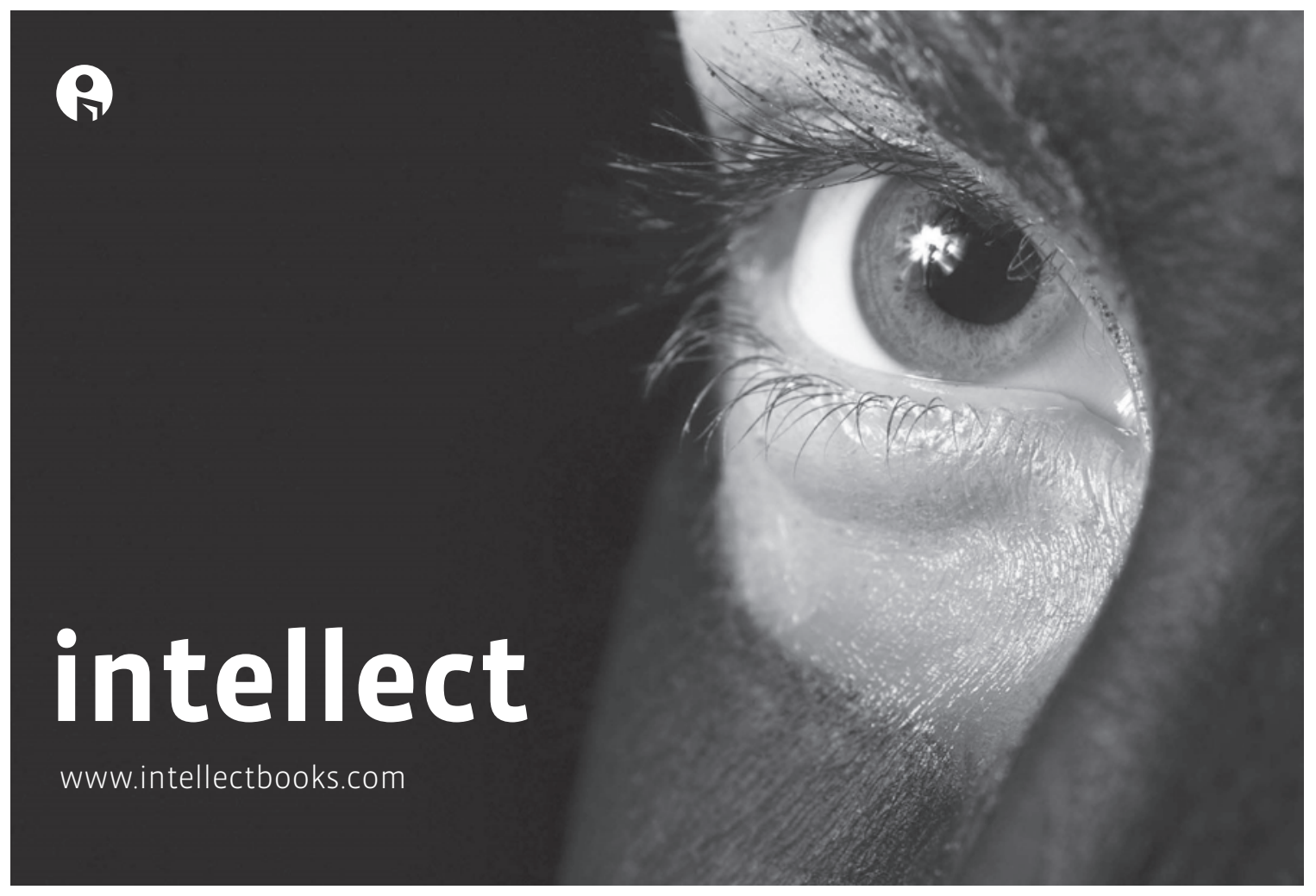

\section{Scene}

ISSN: 2044-3714 | Online ISSN: 2044-3722

3 issues per volume | Volume 1, 2013

Scene is dedicated to a critical examination of space and scenic production. Central to this journal is the understanding that the designer's contribution to a production involves much more than providing a visual background. Scene welcomes new critical frameworks for the scholarship of creating a scene and invites contributions which explore all aspects of design contexts for live and recorded performance particularly those which pay attention to the shaping of artistic vision, aesthetic sophistication, critical thinking and craft.

\section{Submissions}

Articles, interviews, visual essays, reports from conferences and festivals are welcome from scholars and practitioners. Contributors are encouraged to approach design for entertainment from any discipline and to turn their attention to practices from all countries and in all languages.

For more details, please see the journal's webpage or contact the editors.

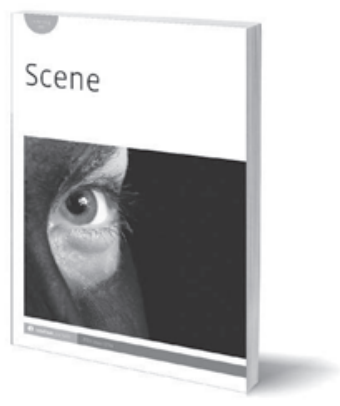

\section{Editors}

Christine White Derby University C.White@derby.ac.uk

Alison Oddey

Nottingham Trent University alison.oddey@ntu.ac.uk

\section{Associate Editors}

Stephen Di Benedetto

University of Miami

Professor Lu Ping

Shanghai Institute of Visual Arts 